\title{
Path Coefficient Analysis and Correlation Coefficients Effects of Different Characters on Yield of Brassica rapa L.
}

\author{
Shahidul Islam ${ }^{1}$, Md. Maksudul Haque ${ }^{2, *}$, Shahidur Rashid Bhuiyan ${ }^{1}$, Sarowar Hossain ${ }^{1}$ \\ ${ }^{1}$ Department of Genetics and Plant Breeding, Sher-e-Bangla Agricultural University, Dhaka, Bangladesh \\ ${ }^{2}$ Plant Breeding Division, Bangladesh Rice Research Institute, Gazipur, Bangladesh
}

Email address:

maksudulhq@gmail.com (Md. M. Haque)

*Corresponding author

\section{To cite this article:}

Shahidul Islam, Md. Maksudul Haque, Shahidur Rashid Bhuiyan, Sarowar Hossain. Path Coefficient Analysis and Correlation Coefficients Effects of Different Characters on Yield of Brassica rapa L. Plant. Vol. 4, No. 6, 2016, pp. 51-55.doi: 10.11648/j.plant.20160406.12

Received: September 18, 2016; Accepted: September 26, 2016; Published: October 27, 2016

\begin{abstract}
A study was conducted by using twenty one (21) $\mathrm{F}_{9}$ populations derived from inter-varietal crosses of Brassica rapa L. Path co-efficient analysis revealed that plant height, number of primary branches per plant, number of siliqua per plant, seeds per siliqua, and siliqua length had the positive direct effect on yield per plant and days to $50 \%$ flowering, number of secondary branches per plant, and thousand seed weight had the negative direct effect on yield per plant. Correlation studyrevealed that yield per plant had significant positive association with plant height, number of primary branches per plant, number of siliqua per plant, seeds per siliqua, and siliqua length (genotypic or phenotypic level). Based on the variability study, some $\mathrm{F}_{9}$ plants showed high heritability for short duration and yield contributing characters were selected from some of the crosses combinations of the intervarital crosses of Brassica rapafor further selection.
\end{abstract}

Keywords: Path Coefficient, Correlation Coefficients, Siliqua, Brassica rapa L.

\section{Introduction}

Brassica oil is the world's third most important sources of edible vegetable oils [1]. Oleiferous Brassicaspecies can be classified into three groups viz; the cole, the rapeseed and the mustard. The mustard groups include species like Brassicajuncea Czern and Coss, Brassicanigra Koch and Brassicacarinata Braun; while the rapeseed groups includes BrassicarapaL. and Brassicanapus L. [2]. The genomic constitutions of the three diploid elemental species of Brassica are AA for Brassicarapa, BB for Brassicanigraand $\mathrm{CC}$ for Brassicaoleracea having diploid chromosome number of 20,16 and, 18 respectively. On the Other hand, the species Brassicajuncea (AABB), Brassicacarinata (BBCC) and Brassicanapus (AACC) are the amphidiploids.

The coles are consumed as vegetables and the other two are the valuable sources of edible oils and proteins. The mustard oil is not used only for edible cooking purpose but also is used in hair dressing, body massing and in different types of pickles preparation. It has also several medicinal values. Oil cake is the most important feed for livestock and is also used as organic manure. The important regions growing these crops include Canada, China, Northern Europe and the Indian subcontinent. In Bangladesh, local cultivars/varieties like $B$. juncea and $B$. napusare highyielding but not short durated. That's why B.rapa are widely grown and it gives moderate yield but early cultivars produce high yield and it is drought and stress resistant. In Bangladesh, Brassica is the most important oilseed crop. The country is facing huge shortage in edible oils. Almost one fourth of the total edible oil consumed annually is imported. The import cost was about 690 million US dollar in 2003 [3]. On Recommended Dietary Allowance (RAD) basis, Bangladesh requires 0.29 million tons of oils which is equivalent to 0.8 million tons of oilseeds; but it produces only about 0.254 million tons, which covers only $45 \%$ of the domestic need [4]. This crop covers the highest acreage which is $78 \%$ of the total oilseed acreage of Bangladesh [3].The average yield of Brassica oilseed in Bangladesh is around $963 \mathrm{~kg} /$ hectare [4].

In Bangladesh there is limited scope to increase acreage due to pressure of other crops and to increase yield due to 
cultivation of the existing low yielding varieties with low inputs, $B$. rapa is the most popular cultivated species. Short duration variety Tori-7 of $B$. rapa is still popular in Bangladesh because it can fit well into the T. Aman-MustardBoro cropping pattern. Early maturity line (SAU sarisha $2 \mathrm{X}$ SAU sarisha 1), combination SAU sarisha 2 X BARI sarisha 6gave higher number of primary branches and number of siliquae / plant. No improved short duration variety of $B$. napusis available to replace this short duration variety. So $B$. rapa is the most popular variety to the farmers. There should be an attempt to develop short duration and high yielding varieties of rapeseed to meet the challenge of edible oils of the country by increasing the production. Segregating materials obtained through different inter-varietal crosses of the species $B$. rapa will give an opportunity to select the desired plant types to meet the existing demand. Therefore, this study was carried out with following objectives: to study the variability among $F_{9}$ generation materials for selection of desired lines, to study the inter-relationship and effect of characters on yield and to select early maturing, high yielding lines for release.

\section{Materials and Methods}

The present study was carried out in the Experimental Farm, Sher-e-Bangla Agricultural University (SAU), Dhaka during Rabi season. A total number of 19 (nineteen) materials were used in this experiment. Where were $F_{9}$ segregating generation materials and six check varieties (tester). The seeds of testers and $\mathrm{F}_{9}$ materials were laid out in a randomized complete block design (RCBD) with three replications.

\section{Statistical analysis}

The data were analyzed for different components. Phenotypic and genotypic variance was estimated by the formula used Johnson [5]. Heritability and genetic advance were measured using the formula given by [6-7]. Genotypic and phenotypic co-efficient of variation was calculated by the formula of Burton [8]. Simple correlation coefficient was obtained using the formula suggested by $[9,6]$ and path coefficient analysis was done following the method outlined by [10].

i) Path co-efficient analysis: Path co-efficient analysis was done according to the procedure employed by [10] also quoted in [6 and 11] using simple correlation values. In path analysis, correlation co-efficient is partitioned into direct and indirect of independent variables on the dependent variable.

In order to estimate direct andindirect effect of the correlated characters, say $\mathrm{x} 1, \mathrm{x} 2$ and $\mathrm{x} 3$ yield $\mathrm{y}$, a set of simultaneous equations (three equations in this example) is required to be formulated as shown blow;

$$
\begin{aligned}
& \mathrm{r}_{\mathrm{yx} 1}=\mathrm{P}_{\mathrm{yx} 1}+\mathrm{P}_{\mathrm{yx} 2} \mathrm{r}_{\mathrm{xlx} 2}+\mathrm{P}_{\mathrm{yx} 3} \mathrm{r}_{\mathrm{x} 1 \mathrm{x} 3} \\
& \mathrm{r}_{\mathrm{yx} 2}=\mathrm{P}_{\mathrm{yx} 1} \mathrm{r}_{\mathrm{x} 1 \mathrm{x} 2}+\mathrm{P}_{\mathrm{yx} 2}+\mathrm{P}_{\mathrm{yx} 3} \mathrm{r}_{\mathrm{x} 2 \mathrm{x} 3} \\
& \mathrm{r}_{\mathrm{yx} 3}=\mathrm{P}_{\mathrm{yx} 1} \mathrm{r}_{\mathrm{x} 1 \mathrm{x} 3}+\mathrm{P}_{\mathrm{yx} 2} \mathrm{r}_{\mathrm{x} 2 \mathrm{x} 3}+\mathrm{P}_{\mathrm{yx} 3}
\end{aligned}
$$

Where, r's denotes simple correlation co-efficient and P's denote path co-efficient (Unknown). P's in the above equations may be conveniently solved by arranging them in matrix from.

Total correlation, say between $\mathrm{x}_{1}$ and $\mathrm{y}$ is thus partitioned as follows:

$\mathrm{P}_{\mathrm{yx} 1}=$ The direct effect of $\mathrm{x}_{1}$ on $\mathrm{Y}$.

$\mathrm{P}_{\mathrm{yx} 2} \mathrm{r}_{\mathrm{xlx} 2}=$ The indirect effect of $\mathrm{x}_{1}$ via $\mathrm{x}_{2}$ on $\mathrm{y}$

$\mathrm{P}_{\mathrm{yx} 3} \mathrm{r}_{\mathrm{x} 1 \times 3}=$ The indirect effect of $\mathrm{x}_{1}$ via $\mathrm{x}_{3}$

After calculating the direct and indirect effect of the characters, residual effect $(\mathrm{R})$ was calculated by using the formula given below [6]:

$\mathrm{P}_{\mathrm{RY}}^{2}=1-\sum \mathrm{P}_{\text {iy. }} \mathrm{r}_{\mathrm{iy}}$

Where, $\mathrm{P}_{\mathrm{RY}}^{2}=\left(\mathrm{R}^{2}\right)$; and hence residual effect, $\mathrm{R}=\left(\mathrm{P}_{\mathrm{RY}}{ }^{1 / 2}\right.$

$P_{\text {iy }}=$ Direct effect of the character on yield

$\mathrm{r}_{\mathrm{iy}}=$ Correlation of the character with yield.

ii) Estimation of Genotypic and Phenotypic Co-efficient of variation: Genotypic and phenotypic co-efficient of variation were calculated by the following formula [8].

$$
\begin{aligned}
& G C V=\frac{\delta \mathrm{g} \times 100}{\overline{\mathrm{x}}} \\
& P C V=\frac{\delta \mathrm{p} \times 100}{\overline{\mathrm{x}}}
\end{aligned}
$$

Where, GCV= Genotypic co-efficient of variation

$\mathrm{PCV}=$ Phenotypic co-efficient of variation

$\Delta \mathrm{g}=$ Genotypic standard deviation

$\Delta \mathrm{p}=$ Phenotypic standard deviation

$\overline{\mathrm{x}}=$ Population mean

\section{Results and Discussion}

\subsection{Path Co-efficient Analysis}

Association of character determined by correlation coefficient may not provide an exact picture of the relative importance of direct and indirect influence of each of yield components on seed yield per plant. In order to find out a clear picture of the inter-relationship between seed yield per plant and other yield attributes, direct and indirect effects were worked out using path analysis at genotypic level which also measured the relative importance of each component. Seed yield per plant was considered as a resultant (dependent) variable and days to $50 \%$ flowering, days to maturity, plant height, number of primary branches/plant, number of secondary branches/plant, length of siliqua, number of seeds/siliqua and 1000 seeds weight were casual (independent) variables. The results of path co-efficient analysis using $\mathrm{F}_{9}$ materials of Brassica rapa were presented in Table 1.

Path analysis revealed that plant height had positive direct effect $(0.347)$ on yield per plant followed by negative indirect effect on number of primary branches per plant (-0.146) and siliqua per plant $(-0.110)$. Positive indirect effect through number of secondary branches per plant (0.038).

Length of siliqua (0.059), seeds per siliqua (0.026), days to 
$80 \%$ maturity (0.021) and 1000 seed weight (0.065) (Table 1). Singh [6] reported plant height, siliquae per plant and seeds per siliqua had high positive direct effect on seed yield.Number of primary branches per plant had negative direct effect on yield per plant $(-0.502)$. This trait had positive indirect effect on seeds per siliqua $(0.015)$. On the other hand negative indirect effect was found on number of number of siliqua per plant $(-0.006)$ (Table 1). Number of primary braches per plant had the highest negative direct effect on seed yield was observed Chaudhary [12] while working with 42 strains of mustard.

Number of secondary branches per plant had positive direct effect $(0.232)$ on yield per plant and negative indirect effect on primary branches per plant $(-0.209)$, siliqua per plant $(-0.057)$, seeds per siliqua $(-0.004)$ and days to $80 \%$ maturity $(-0.003)$. On the other hand, this trait showed positive indirect effect on Plant height (0.057), length of siliqua (0.001) and 1000 seed weight (0.089) (Table 1). Chaudhary [13] found the number of secondary branches per plant had positive direct effect $(0.295)$ on yield per plant.

Path co-efficient analysis revealed thatnumber of siliqua per plant had negative direct effect $(-0.208)$ on seed yield followed by positive indirect effect on plant height (0.184), secondary branches per plant (0.064) and thousand seed weight $(0.120)$. And this trait had negative indirect effect on number of primary branches per plant $(-0.016)$, length of siliqua (-0.020), seeds per siliqua (-0.007) and number days to $80 \%$ maturity $(-0.007)$ (Table 1$)$.Yadavaet al. [14] found the number of siliquae per plant had the highest positive direct effect on seed yield.
Path analysis revealed that length of siliqua had direct positive effect $(0.273)$ on yield per plant. This trait had also indirect positive effect on seeds per siliqua (0.018). On the other hand length of siliqua showed indirect negative effect on number of primary branches per plant $(-0.203)$, number of secondary branches per plant $(-0.273), 1000$ seed $(-0.012)$ (Table 1).

Seeds per siliqua had positive direct effect (0.066) on yield per plant and positive indirect effect on plant height (0.137), number of siliqua per plant (0.021), siliqua length (0.073) and thousand seed weight $(0.040)$. On the other hand, this trait showed negative indirect effect on number of primary branches per plant (-0.293), secondary branches per plant ($0.013)$, days to $80 \%$ maturity $(-0.011)$ and Pearson correlation with yield $(-0.003)$ (Table 1$)$.

Thousand seed weight had positive direct effect on yield per plant (0.428) and negative indirect effect on number of primary branches per plant $(-0.022)$, siliqua per plant ($0.058)$, length of siliqua $(-0.007)$ and days to $80 \%$ maturity ($0.030)$. On the other hand, this trait showed positive indirect effect on number of plant height $(0.053)$, secondary branches per plant (0.048) and seeds per siliqua (0.006) (Table 1).

Through path analysis the residual effect was observed. The residual effect $(\mathrm{R})$ was 0.430 , which indicating the character under study contributed $44.1 \%$ of the seed yield per plant (Table 1).It is suggested that there were some others factors those contributed $55.1 \%$ to the seed yield per plant not included in the present study may exert significant effect on seed yield.

Table 1. Path coefficient analysis showing direct and indirect effects of different characters on yield of Brassica rapaL..

\begin{tabular}{|c|c|c|c|c|c|c|c|c|c|c|}
\hline Characters & $\begin{array}{l}\text { Direct } \\
\text { effect }\end{array}$ & $\begin{array}{l}\text { Plant } \\
\text { height } \\
(\mathrm{cm}) \\
\end{array}$ & $\begin{array}{l}\text { Primary } \\
\text { branches } \\
\text { per plant } \\
\end{array}$ & $\begin{array}{l}\text { Secondary } \\
\text { branches } \\
\text { per plant }\end{array}$ & $\begin{array}{l}\text { Siliqua } \\
\text { per plant }\end{array}$ & $\begin{array}{l}\text { Length of } \\
\text { siliqua }\end{array}$ & $\begin{array}{l}\text { Seeds } \\
\text { per } \\
\text { siliqua } \\
\end{array}$ & $\begin{array}{l}\text { Days to } \\
80 \% \\
\text { maturity } \\
\end{array}$ & $\begin{array}{l}1000 \\
\text { seed } \\
\text { weight }\end{array}$ & $\begin{array}{l}\text { Pearson } \\
\text { correlation } \\
\text { with yield } \\
\end{array}$ \\
\hline Plant height $(\mathrm{cm})$ & 0.347 & & -0.146 & 0.038 & -0.110 & 0.059 & 0.026 & 0.021 & 0.065 & $0.300 * *$ \\
\hline Primary branches per plant & -0.502 & 0.101 & & 0.097 & -0.006 & 0.110 & 0.039 & 0.017 & 0.018 & -0.126 \\
\hline Secondary branches per plant & 0.232 & 0.057 & -0.209 & & -0.057 & 0.001 & -0.004 & -0.003 & 0.089 & 0.106 \\
\hline Siliqua per plant & -0.208 & 0.184 & -0.016 & 0.064 & & -0.020 & -0.007 & -0.007 & 0.120 & 0.112 \\
\hline Length of siliqua & 0.273 & 0.075 & -0.203 & 0.001 & 0.015 & & 0.018 & 0.042 & -0.012 & 0.204 \\
\hline Days to $80 \%$ maturity & 0.190 & 0.038 & -0.044 & -0.004 & 0.007 & 0.060 & -0.004 & & -0.069 & 0.175 \\
\hline 1000 SEED WEIGHT & 0.428 & 0.053 & -0.022 & 0.048 & -0.058 & -0.007 & 0.006 & -0.030 & & $0.418 * *$ \\
\hline
\end{tabular}

Residual effect: 0.430

$* *=$ Significant at $1 \%$.

$*=$ Significant at $5 \%$.

\subsection{Correlation Co-efficient}

Seed yield is a complex product being influenced by several quantitative traits. Some of these traits are highly associated with seed yield. The analysis of the relationship among those traits and their association with seed yield is very much essential to establish selection criteria. Breeders always look for genetic variation among traits to select desirable type. Correlation co-efficient between pairs of trait for $\mathrm{F}_{9}$ materials of B. rapa are shown in Table 2. Breeders always look for genetic variation among traits to select desirable type. Correlation co-efficient between pairs of trait for $\mathrm{F}_{9}$ materials of B. rapa are shown in Table 2.

\subsection{Plant Height (Cm)}

Plant height showed positive significant interaction between number of siliqua per plant $(\mathrm{G}=0.516)$ and seeds per siliqua $(\mathrm{G}=0.329)$ followed by positive interaction with secondary branches per plant $(\mathrm{G}=0.085)$, length of siliqua $(\mathrm{G}=0.032)$, days to $80 \%$ maturity $(\mathrm{G}=0.247), 1000$ seed weight $(\mathrm{G}=0.159)$ and seed yield per plant $(\mathrm{G}=0.263)$. Whereas positive significant interaction was found in number of primary branches per plant $(\mathrm{P}=0.280)$, siliqua per plant $(\mathrm{P}=0.529)$ and seed yield per plant $(\mathrm{P}=0.292)$ followed by positive interaction was found in secondary branches per plant ( $\mathrm{P}=0.156)$, length of siliqua $(\mathrm{P}=0.208)$, seeds per siliqua 
$(\mathrm{P}=0.042)$, days to $80 \%$ maturity $(\mathrm{P}=0.118)$ and 1000 seed weight $(\mathrm{P}=0.160) \quad$ (Table 2). These findings are close resemblance to the reports of [13-14].

\subsection{Number of Primary Branches Per Plant}

Number of primary branches per plant showed positive significant interaction with number of secondary branches per plant $(\mathrm{G}=0.399)$ followed by positive interaction with seeds per siliqua $(\mathrm{G}=0.548)$. Whereas the negative significant interaction was seed yield per plant $(\mathrm{G}=-0.343)$ but negative interaction was found in siliqua per plant $(\mathrm{G}=$ 0.078) (Table 2). Singh et al. (1987) reported number of primary branches per plant negatively correlated with siliqua length and 1000 seed weight positively correlated with number of siliqua per plant.

\subsection{Number of Secondary Branches Per Plant}

Number of secondary branches per plant showednegative significant interaction with length of siliqua $(\mathrm{G}=-0.122, \mathrm{P}=-$ $0.008)$ seeds per siliqua $(\mathrm{G}=-0.159, \mathrm{P}=-0.066)$ and days to $80 \%$ maturity $(\mathrm{P}=-0.010)$ followed by positive interaction with siliqua per plant $(\mathrm{G}=0.254)$, thousand seed weight $(\mathrm{G}=$ $0.194, \mathrm{P}=0.215)$ and yield per plant $(\mathrm{G}=0.051, \mathrm{P}=0.094)$ (Table 2).

\subsection{Number of SiliquaPer Plant}

Table 2. Genotypic correlation coefficients among different pairs of yield and yield contributing characters for different genotype of Brassica rapaL..

\begin{tabular}{|c|c|c|c|c|c|c|c|c|c|}
\hline Characters & & $\begin{array}{l}\text { Primary } \\
\text { branches } \\
\text { per plant }\end{array}$ & $\begin{array}{l}\text { Secondary } \\
\text { branchess } \\
\text { per plant }\end{array}$ & $\begin{array}{l}\text { Siliqua } \\
\text { per plant }\end{array}$ & $\begin{array}{l}\text { Length } \\
\text { of siliqua } \\
\text { (cm) } \\
\end{array}$ & $\begin{array}{l}\text { Seeds } \\
\text { per } \\
\text { siliqua }\end{array}$ & $\begin{array}{l}\text { Days to } \\
80 \% \\
\text { maturity }\end{array}$ & $\begin{array}{l}1000 \text { seed } \\
\text { weight } \\
(\mathrm{gm})\end{array}$ & $\begin{array}{l}\text { Seed yield } \\
\text { per plant } \\
(\mathrm{gm}) \\
\end{array}$ \\
\hline \multirow{2}{*}{ Plant height $(\mathrm{cm})$} & G & 0.142 & 0.085 & $0.516^{* *}$ & 0.032 & $0.329 * *$ & 0.247 & 0.159 & 0.263 \\
\hline & $\mathrm{P}$ & $0.280 *$ & 0.156 & $0.529 * *$ & 0.208 & 0.042 & 0.118 & 0.16 & $0.292 *$ \\
\hline \multirow{2}{*}{ Primary branches per plant } & G & & $0.399 * *$ & -0.078 & 0.245 & $0.548 * *$ & 0.21 & 0.005 & $-0.343 * *$ \\
\hline & $\mathrm{P}$ & & $0.409 * *$ & 0.021 & $0.397 * *$ & $0.579 * *$ & 0.104 & 0.055 & 0 \\
\hline \multirow{2}{*}{ Secondary branches per plant } & G & & & 0.254 & -0.122 & -0.159 & 0.009 & 0.194 & 0.051 \\
\hline & $\mathrm{P}$ & & & 0.273 & -0.008 & -0.066 & -0.01 & 0.215 & 0.094 \\
\hline \multirow{2}{*}{ Siliqua per plant } & G & & & & -0.237 & -0.197 & -0.069 & $0.318 * *$ & 0.061 \\
\hline & $\mathrm{P}$ & & & & -0.08 & -0.11 & -0.03 & $0.285^{*}$ & 0.105 \\
\hline \multirow{2}{*}{ Length of siliqua (cm) } & G & & & & & 0.045 & $0.480 * *$ & -0.131 & 0.124 \\
\hline & $\mathrm{P}$ & & & & & 0.178 & 0.227 & -0.018 & 0.195 \\
\hline \multirow{2}{*}{ Seeds per siliqua } & G & & & & & & -0.114 & 0.108 & -0.119 \\
\hline & $\mathrm{P}$ & & & & & & -0.049 & 0.1 & -0.018 \\
\hline \multirow{2}{*}{ Days to $80 \%$ maturity } & G & & & & & & & -0.07 & $0.363 * *$ \\
\hline & $\mathrm{P}$ & & & & & & & -0.166 & 0.191 \\
\hline \multirow{2}{*}{1000 seeds weight $(\mathrm{g})$} & G & & & & & & & & $0.410 * *$ \\
\hline & $\mathrm{P}$ & & & & & & & & $0.433 * *$ \\
\hline
\end{tabular}

$* *=$ Significant at $1 \%$.

$*=$ Significant at $5 \%$.

\section{Conclusion}

Path co-efficient analysis revealed that days to plant height, number of secondary branches per plant, length of siliqua, seeds per siliqua, days to $80 \%$ maturity and thousand seed weight had the positive direct effect on yield per plant and primary branches per plant and siliqua per plant had the negative direct effect on yield per plant.Correlation revealed that yield per plant had
Siliqua per plant showed positive significant interaction with thousand seed weight $(\mathrm{G}=0.318, \mathrm{P}=0.285)$ followed by positive interaction with seed yield per plant $(\mathrm{G}=0.061, \mathrm{P}=$ 0.105). Whereas rest parameter the negative significant interaction (Table 2). Das et al [15] reported number of siliquae/plant showed significant and positive correlation with $\mathrm{r}$ of seeds/siliqua and 1000 seed weight.

\subsection{Length of Siliqua (Cm)}

Length of siliqua showed positive significant interaction days to $80 \%$ maturity $(\mathrm{G}=0.480)$ (Table 2$)$. Das et al. [16] reported that seed yield per plant positively correlated with length of siliqua and seeds per siliqua.

\subsection{Seeds PerSiliqua}

Seeds per siliqua showed significant positive interaction with 1000 seed weight $(\mathrm{G}=0.108, \mathrm{P}=0.100$ ) (Table 2). Dhillonet al [17] reported that number of siliqua per plant, thousand seed weight were positively correlated with seed yield. Tyagiet at. [18] reported that no. of seeds per siliqua had positive and significant effects on seed yield per plant.

\subsection{Thousand Seed Weight}

Thousand seed weight showed significant positive interaction with yield per plant (Table 2). 
rapafor further selection.

\section{References}

[1] Downey, R. K. (1990). Brassica oilseed breedingachievements and opportunities. Pl. Breed. Abstracts. 60: I 165-1 170.

[2] Yarnell, S.H. (1956). Cytogenetics of vegetable crops. Crucifers Bot. Rev. 22 (2): 81-166

[3] BBS (2004). Statistical Yearbook of Bangladesh. Bangladesh Bureau of Statistics. Statistic Division, Ministry of Planning, Govt. of the People's Republic of Bangladesh. p. 96.

[4] FAO. (2004). Production Year Book, Food and Agricultural Organization of United Nations, Rome 00108, Italy. Vol. 57.pp. 115-133.

[5] Johnson, Herbert, W. Robinson, H. F. and Comstock, R.E. (1955). Estimates of genetic and environmental variability in soyabeans. Agron. J. 47: 3 14-3 I 8.

[6] Singh, R. K. and Chaudhary, B. D. (1985). Biometrical methods in quantitative genetic analysis. Kalyani Publishers, New Delhi, India. p. 56.

[7] Allard. R. W. (1960). Principles of Plant Breeding. John Willey and Sons. Inc. New York. p. 36.

[8] Burton, G.W. (1952). Quaniitative inheritance in grass pea. Proc. 6 thGrassl. Cong. 1:277-283.

[9] Clarke, G. M. (1973). Statistics and Experimental Design. Edward Amold. London.
[10] Dewey, D. R. and Lu, K. H. (1959). A correlation and path coefficient analysis of components of crested wheat grass seed production. Agron. J. 51:515-518.

[11] Dabholkar, A. R. (1992). Elements of Biometrical Genetics. Concept publishing, New Dhelhi, India.

[12] Chowdhury, B. D., Thakural, S. K., Singh, D. P. and Singh, P. (1987). Genetics of yield and its components in Indian mustard. Narenda Deva J. Agril. Res. 3 (1): 37-43.

[13] Chaudhary, L. B. and Prasad, B. (1987). Genetic variation and heritability of quantitative characters in Indian mustard. Indian J. Agril. Sci. 38 (5): 820-825.

[14] Yadava O. P., Yadav, T. P. and Kumar, P. (1996). Combining ability studies for seed yield. i components characters and oil content in Indian mustard (Brassica juncea L. CzernzuCoss.). J. Oil Seed Res. 9 (1): 4-20.

[15] Das, M. L., Rahman, A., Khan, M. H. R. and Miah, A. J. (1984). Correlation and path coefficient studies in soybean, Bangladesh J. Bot. 7 (1): 1-5.

[16] Das, M. L., Rahman, A., Malek, M. A. and Pathan A. J. (1995). Stability and fatty acid analysis for selecting promising mutants of rapeseed. Bangladesh J. Nuclear Agric.11: 1- 8

[17] Dhillon, S. S., Laban K. S. and Ahuja, K. L. (1990). Association analysis in Indian Mustard. Journal Research. 27 (3): 3 85-3 88.

[18] Tyagi, M. K., Chauhan, J. S., Kumar, P. R. and Singla K. H. (2001). Estimation of heterosisIndian mustard. AnnalsAgric. Bio. Res.6 (20): 193-200. 